\title{
Inhibition of thrombin-catalyzed reactions in blood coagulation and platelet activation by heparin fractions in the absence of antithrombin III
}

Citation for published version (APA):

Baruch, D., Lindhout, T., Wagenvoort, R., \& Hemker, H. C. (1986). Inhibition of thrombin-catalyzed reactions in blood coagulation and platelet activation by heparin fractions in the absence of antithrombin III. Haemostasis, 16(2), 71-81. https://doi.org/10.1159/000215276

Document status and date:

Published: 01/01/1986

DOI:

10.1159/000215276

Document Version:

Other version

Please check the document version of this publication:

- A submitted manuscript is the version of the article upon submission and before peer-review. There can be important differences between the submitted version and the official published version of record.

People interested in the research are advised to contact the author for the final version of the publication, or visit the DOI to the publisher's website.

- The final author version and the galley proof are versions of the publication after peer review.

- The final published version features the final layout of the paper including the volume, issue and page numbers.

Link to publication

\footnotetext{
General rights rights.

- You may freely distribute the URL identifying the publication in the public portal. please follow below link for the End User Agreement:

www.umlib.nl/taverne-license

Take down policy

If you believe that this document breaches copyright please contact us at:

repository@maastrichtuniversity.nl

providing details and we will investigate your claim.
}

Copyright and moral rights for the publications made accessible in the public portal are retained by the authors and/or other copyright owners and it is a condition of accessing publications that users recognise and abide by the legal requirements associated with these

- Users may download and print one copy of any publication from the public portal for the purpose of private study or research.

- You may not further distribute the material or use it for any profit-making activity or commercial gain

If the publication is distributed under the terms of Article 25fa of the Dutch Copyright Act, indicated by the "Taverne" license above, 


\title{
Inhibition of Thrombin-Catalyzed Reactions in Blood Coagulation and Platelet Activation by Heparin Fractions in the Absence of Antithrombin III
}

\author{
Dominique Baruch, Theo Lindhout, Rob Wagenvoord, H. Coenraad Hemker
}

Department of Biochemistry, University of Limburg, Maastricht, The Netherlands

Key Words. Thrombin · Heparin · Factor V · Factor VIII · Platelets

Abstract. The antithrombin-III-independent effect of heparin was studied in the following thrombin-catalyzed reactions: activation of purified plasma factor $\mathrm{V}$ and partially purified plasma factor VIII:C, generation of factor $\mathrm{V}_{\mathrm{a}}$ from the platelets and, in the presence of collagen, of the platelet procoagulant activity. Five heparin fractions and a heparinoid were compared to crude heparin. Crude heparin was a more potent inhibitor of these reactions than the fractions or the heparinoid. The inhibitory action of heparin (fractions) appeared to be the result of the formation of a complex between heparin and thrombin that alters the specificity of thrombin towards high molecular weight substrates. The inhibition of these thrombindependent feedback reactions in blood coagulation might be of importance in the mechanisms for the dissociation between the antithrombotic and hemorrhagic properties of low molecular weight heparins.

\section{Introduction}

Heparin is one of the most important drugs for the treatment and prevention of venous thrombosis and thromboembolism. However, it still presents many puzzling questions on different levels to clinicians and clinical chemists, biologists, biochemists and certainly not least for the pharmaceutical industry. Clinicians and clinical chemists know that the major drawback to the therapeutical use of heparin is the absence of any reliable laboratory test to keep the patient in the narrow range that ensures an efficient anti- thrombotic action but will not cause a hemorrhagic tendency. From the literature it is evident that the properties of heparin to catalyze factor $\mathrm{X}_{\mathrm{a}}$ and/or thrombin inactivation by antithrombin III do not sufficiently reflect the complexity of in vivo heparin actions. Research over the last few years has led to the development of heparin fractions of known compositions which allowed considerable progress in understanding the structure-function relationships. Our contribution, as biochemists of blood coagulation, is to identify the complete spectrum of heparin-sensitive reactions, to develop a relevant in vitro de- 
termination of the action of heparin and to establish their correlation with in vivo effects.

As thrombin formation is the central process in hemostasis and thrombosis, the inhibition by heparin of thrombin formation has been our main focus of interest. It should be appreciated that heparin can inhibit thrombin by 2 separate mechanisms, i.e. the antithrombin activity can be either antithrombin-III-dependent or -independent.

\section{Thrombin Generation and Feedback Mechanisms}

The mechanisms leading to thrombin formation are, on the one hand, a series of proenzyme activation reactions (factor VII $\rightarrow$ factor $\mathrm{X} \rightarrow$ factor II) and on the other hand interactions at a phospholipid-solute interphase [1]. Procoagulant, negatively charged phospholipids are provided by the membrane of activated platelets and wounded cells [2]. The assembly of an enzymatic complex at the phospholipid surface is completed by the presence of non-enzymatic protein cofactors (respectively tissue factor, factor $\mathrm{VIII}_{\mathrm{a}}$ and factor $V_{a}$ ) [3-5]. The interaction of thrombin and platelets is a complicated process. Thrombin once formed in trace amounts governs a set of positive feedback reactions. Thrombin is a potent platelet activator and induces the release reactions by which factor $\mathrm{V}$ becomes available. Platelet factor $\mathrm{V}$ seems to contribute more to thrombin generation and hence to hemostasis and coagulation than plasma factor $\mathrm{V}$ does. This was demonstrated within a group of factor$\mathrm{V}$-deficient patients, where the severity of bleeding was shown to depend on the platelet rather than on the plasma factor $\mathrm{V}$ deficiency [6]. Thrombin also converts factor $\mathrm{V}$ and factor VIII into their activated forms. Together with collagen, thrombin generates the appearance of a procoagulant surface at the outer membrane of the platelets [2]. If the thrombin formation were not controlled by natural inhibitors and regulatory processes (such as inactivation of factors $\mathrm{V}_{\mathrm{a}}$ and $\mathrm{VIII}_{\mathrm{a}}$ by activated protein $\mathrm{C}$ ), these coagulation factors and platelet interactions would result in an explosive thrombin formation.

\section{The Antithrombin-III-Dependent Action} of Heparin

The main anticoagulant function of heparin is to enhance the inactivation of the serine proteases of blood coagulation (thrombin, factor $\mathrm{X}_{\mathrm{a}}, \mathrm{IX}_{\mathrm{a}}, \mathrm{XI}_{\mathrm{a}}$ and $\mathrm{XII}_{\mathrm{a}}$ ) by antithrombin III (AT III). Three models are currently described. (a) Heparin binds to AT III, inducing a conformational change $[7,8]$; (b) the reactivity of thrombin with AT III is enhanced by the binding of heparin to thrombin $[9,10]$; and (c) a ternary complex is formed and stabilized by the interaction of AT III and thrombin with heparin, the socalled template model [11-13]. These models are not mutually exclusive.

Factor $\mathrm{X}_{\mathrm{a}}$ inactivation by the heparin-AT III complex is accounted for by the interaction of factor $\mathrm{X}_{\mathrm{a}}$ with AT III and not by the interaction of factor $\mathrm{X}_{\mathrm{a}}$ with heparin bound to AT III. Factor $\mathrm{XII}_{\mathrm{a}}$ is inhibited in the same way. The saccharide structure required to potentiate the inactivation of factor $\mathrm{X}_{\mathrm{a}}$ and factor $\mathrm{XII}_{\mathrm{a}}$ is contained within the $\mathrm{AT}$ III-binding region [14]. Heparin fractions with a molecular weight higher than 3,400 are equally active [15]. On the contrary, thrombin and factors $\mathrm{IX}_{\mathrm{a}}$ and $\mathrm{XI}_{\mathrm{a}}$ can bind to the heparin molecule as well as to the AT III molecule. The potency of heparin in catalyzing the AT III thrombin reaction increases with the molecular weight of heparin [16]. At 
high concentrations, heparin has an additional effect by catalyzing the inhibition of thrombin by heparin cofactor II [17].

However, because thrombin formation is a phospholipid-bound process, the inactivation of the serine proteases of blood coagulation has to be considered as it occurs at the phospholipid-solute interphase, where the enzyme is located when it is physiologically active, rather than on the free enzyme. It has already been known for several years $[18,19]$ that factor $X_{a}$ bound to phospholipids is much less accessible to the inactivation by AT III-heparin than free factor $\mathrm{X}_{\mathrm{a}}$ is. This was recently demonstrated to be also the case when factor $\mathrm{X}_{\mathrm{a}}$ and factor $\mathrm{V}_{\mathrm{a}}$ bind to activated platelets, therefore requiring that these complexes are cleared from blood before the heparin therapy can be effective $[20,21]$.

The Antithrombin-III-Independent Effect of Heparin

Evidence for an AT-III-independent effect of heparin in reactions of blood coagulation and hemostasis is three-fold.

(1) Some heparin fractions with a low affinity for AT III, which are virtually devoid of any antithrombin or antifactor $\mathrm{X}_{\mathrm{a}}$ activity in vitro significantly increased hemorrhage without influencing the in vivo antithrombotic effect in animal experimental models [22]. Furthermore this low affinity heparin fraction potentiated the antithrombotic action of a high affinity heparin oligosaccharide of a molecular weight lower than 3,500 which only had an antifactor $\mathrm{X}_{\mathrm{a}}$ activity in vitro [23].

(2) In a system consisting of purified coagulation factors and synthetic phospholipids, heparin can inhibit prothrombin and factor $\mathrm{X}$ activation. This effect was attributed to the deplacement of the bound proteins from the phospholipid surface [24-26]. However, these experimental results can alternatively be explained by an effect of heparin on the thrombin-catalyzed factor VIII activation. As the effect of heparin in these experiments was practically abolished if the activated factor VIII was present, the latter explanation seems more probable. Also the fact that in an AT-III-depleted plasma the effect of heparin on the inhibition of factor $\mathrm{X}_{\mathrm{a}}$ or thrombin generation is almost negligible, supports this notion [27]. Comparison of crude heparin and low affinity heparin in prothrombin activation in AT-III-depleted plasma showed that the inhibitory effect of both heparins was similar. These experiments do not exclude an effect due to other serine protease inhibitors. No further insight was brought in the mechanism underlying the deplacing effect by heparin of protein-lipid interactions [28].

(3) Conflicting data have been reported showing that heparin either induced [29] or inhibited platelet aggregation [30]. It was shown that some of the heparin effects were related to an interaction with platelet functions [31]. Bleeding caused by heparin has been attributed to a direct effect on platelets. The original observation of Salzman et al. [32] that high molecular weight, low AT III affinity heparin fractions, were more reactive on platelets than low molecular weight, high AT III affinity fractions, suggested a correlation between the hemorrhagic effect of heparin and the anticoagulant properties in vitro. However, this correlation is far from being a strong one [33].

In this study, we show that an AT-IIIindependent effect of heparin in blood coagulation and platelet reactions might be the result of an interaction between thrombin and heparin. To this end, we used purified proteins, synthetic phospholipids or washed platelets under well defined kinetic condi- 
tions, together with different heparin fractions of known antithrombotic/hemorrhagic properties [34-37].

\section{Materials and Methods}

Experimental procedures for protein and phospholipid preparation as well as platelet isolation are as described earlier [38]. Purification of bovine factor VIII:C was performed by differential precipitation by polyethylene glycol. The determination of the platelet factor $\mathrm{V}_{\mathrm{a}}$ generation upon the addition of thrombin, and of the platelet procoagulant activity in the presence of thrombin and collagen, has been reported previously [38].

\section{Heparin Fractions}

We were interested in measuring the effect of heparin fractions that had already been used in clinical trials and in vivo animal experimental models [3437]. They were supplied by the following laboratories: Choay Institute (CY 216, an ethanol precipitation fragment; CY 222, a fragment obtained by nitrous acid depolymerization), Pharmuka Laboratories (FF 32038, a crude heparin; PK 10169, obtained by controlled depolymerization; EMT 966, EMT 967, obtained by gel filtration of PK 10169) and Organon Laboratories (crude heparin and Org 10172, a sulphated mucopolysaccharide). The average molecular weights, antifactor $\mathrm{X}_{\mathrm{a}}$ and antithrombin activities are listed in table I.

\section{Purified Plasma Factor V Activation}

Bovine factor $\mathrm{V}(100 \mathrm{n} M)$ was incubated for $5 \mathrm{~min}$ at $37^{\circ} \mathrm{C}$ in the presence of $3 \mathrm{mM} \mathrm{CaCl}$. The reaction was started by the addition of thrombin (usually 0.3 $\mathrm{n} M$ ). Aliquots were taken in time, diluted 1:1,000 in buffer containing $50 \mathrm{~m} M$ Tris, $175 \mathrm{mM} \mathrm{NaCl}, 5 \mathrm{~m} M$ $\mathrm{CaCl}_{2}$ and $0.5 \mathrm{mg} / \mathrm{ml} \mathrm{HSA}$, pH 7.9. Factor $\mathrm{V}_{\mathrm{a}}$ activity was measured as previously described [38].

Partially Purified Factor VIII:C Activation

Partially purified factor VIII:C was activated by bovine thrombin in the following way: factor VIII:C $(20 \mu \mathrm{l}, 27 \mathrm{U} / \mathrm{ml})$ was incubated in $1 \mathrm{ml}$ Michaelis buffer containing $29 \mathrm{mM}$ sodium barbiturate, $29 \mathrm{mM}$ sodium acetate and $116 \mathrm{mM} \mathrm{NaCl}, \mathrm{pH} 7.3$. The reaction was started with the addition of thrombin $(3 \mathrm{n} M)$.
Table I. Characteristics of heparin fractions

\begin{tabular}{lllc}
\hline Compound & $\begin{array}{l}\text { Mean } \\
\text { molecular } \\
\text { weight }\end{array}$ & $\begin{array}{l}\text { Anti } X_{\mathrm{a}} \\
\text { activity } \\
\mathrm{U} / \mathrm{mg}\end{array}$ & $\begin{array}{l}\text { Anti II } \\
\text { activity } \\
\mathrm{U} / \mathrm{mg}\end{array}$ \\
\hline $\begin{array}{l}\text { Crude } \\
\text { heparin }\end{array}$ & 15,000 & 175 & 175 \\
FF 32038 & 15,000 & 165 & 165 \\
Org 10172 & 6,400 & 8 & 0.32 \\
CY 216 & 4,500 & 200 & $10-20$ \\
CY 222 & 2,500 & 250 & $5-15$ \\
PK 10169 & 4,500 & 120 & 30 \\
EMT 966 & 6,500 & 160 & 70 \\
EMT 967 & 3,300 & 100 & 0 \\
\hline
\end{tabular}

Aliquots $(10 \mu \mathrm{l})$ of a factor-VIII $\mathrm{a}$-containing sample were added to the clotting assay containing $60 \mu \mathrm{l}$ factor-VIII-deficient plasma, $4 \mathrm{n} M$ factor $\mathrm{IX}_{\mathrm{a}}, 50 \mu M$ phospholipid [(25\% phosphatidylserine (PS), $75 \%$ phosphatidylcholine (PC)] and $10 \mathrm{mM} \mathrm{CaCl} 2$. The clotting time was recorded on an automatic coagulometer. A calibration curve was established with normal pool plasma activated with $9 \mathrm{n} M$ thrombin in order to determine the amount of factor $\mathrm{VIII}_{\mathrm{a}}$ present in the sample.

\section{Inhibition Studies}

The assessment of a heparin effect on thrombincatalyzed reactions can be made provided that the following conditions are met.

(1) Thrombin formation by the prothrombinase complex can be measured as a function of varying concentrations of an accessory component (factor $\mathrm{V}_{\mathrm{a}}$ or phospholipids) under the conditions where the accessory component under investigation is the only ratelimiting factor of the reaction. Factor $\mathrm{VIII}_{\mathrm{a}}$ can be determined in a clotting assay in a comparable manner.

(2) An effect of heparin on a thrombin-catalyzed reaction can be assessed if the manner in which this reaction depends on the thrombin concentration is known. This is shown, in figure 1 , for the thrombincatalyzed factor VIII activation and in figure 2 for the thrombin-catalyzed factor $\mathrm{V}$ activation. Throughout this study, excess thrombin concentrations were avoided in order to be able to quantitate the heparin 

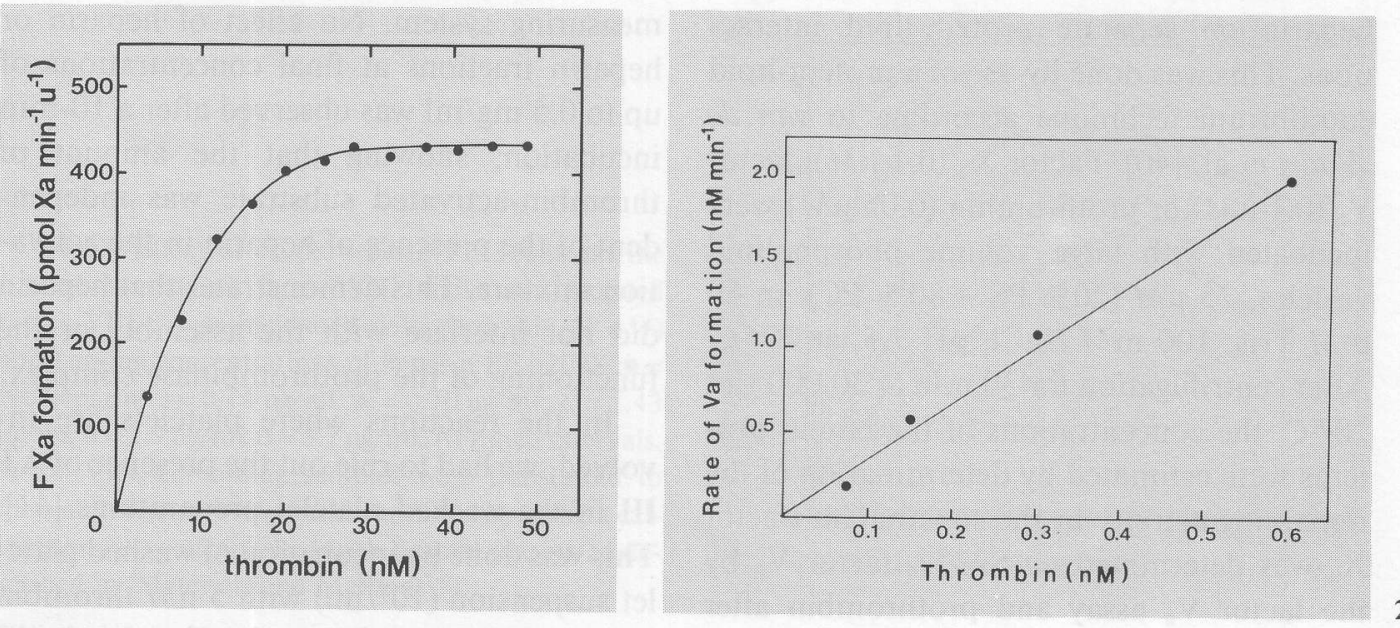

Fig. 1. Dependency of the factor VIII activation on thrombin concentration. Normal plasma is incubated at $37^{\circ} \mathrm{C}$ with varying bovine thrombin concentrations for $15 \mathrm{~s}$. A sample is brought to the factor $\mathrm{X}$ activation mixture containing phospholipids vesicles $\left(25 \% \mathrm{PS} / 75 \% \mathrm{PC}, 5 \times 10^{-5} M\right), \mathrm{CaCl}_{2}(10 \mathrm{mM})$ and factor $\mathrm{IX}_{\mathrm{a}}$ $\left(4.0 \times 10^{-9} M\right)$. The rate of factor $\mathrm{X}$ activation is measured after 2 and $4 \mathrm{~min}$. The results are expressed as rate of the factor $\mathrm{X}_{\mathrm{a}}$ formation per minute per unit factor $\mathrm{VIII}_{\mathrm{a}}$ present in $1 \mathrm{ml}$ plasma.

Fig. 2. Dependency of factor $\mathrm{V}$ activation on thrombin concentration. Purified bovine factor $\mathrm{V}(100 \mathrm{n} M)$ was incubated for $5 \mathrm{~min}$ at $37^{\circ} \mathrm{C}$ in a buffer containing $50 \mathrm{mM}$ Tris, $175 \mathrm{mM} \mathrm{NaCl}, 3 \mathrm{mM} \mathrm{CaCl}$, $0.5 \mathrm{mg}$ human serum albumin $/ \mathrm{ml}$ in the presence of varying thrombin concentrations. Factor $\mathrm{V}_{\mathrm{a}}$ activity was determined as described in 'Materials and Methods'.

effects. We previously showed that a similar relationship exists in the thrombin-catalyzed platelet $\mathrm{V}_{\mathrm{a}}$ generation and thrombin-plus collagen-induced platelet procoagulant activity [38].

(3) The interaction between heparin and thrombin results in the formation of a 1:1 complex. This complex formation leaves unaffected the catalytic site of thrombin towards the synthetic chromogenic substrate, but has an altered enzymatic activity towards macromolecular substrates. In contrast with others [39], we found that heparin and heparin fractions up to $200 \mu \mathrm{g} / \mathrm{ml}$ had no effect on the catalytic efficiency of thrombin on the chromogenic substrate S2338 when the substrate concentration is above or near the $\mathrm{K}_{\mathrm{m}}$ (data not shown).

Upon the formation of a heparin-thrombin complex, the inhibition of the thrombin activity on its macromolecular substrate results in a decrease in the rate of the thrombin-catalyzed reaction. The $\mathrm{IC}_{50}$ is the heparin concentration required to obtain halfmaximal reaction velocity. The $\mathrm{IC}_{50}$ values can be accurately determined by a plot of the reciprocal total heparin concentration versus the ratio $\mathrm{v}_{\mathrm{o}} /\left(\mathrm{v}_{0}-\mathrm{v}\right)$, where $\mathrm{v}_{\mathrm{o}}$ and $\mathrm{v}$ are the velocities of the reaction in the absence and the presence of heparin, respectively.

\section{Results and Discussion}

Demonstration of the Absence of

Interaction of Heparin with Other

Components than Thrombin

Before we could attribute to heparin the observed effects on the thrombin-catalyzed reactions, we had to exclude any effect of heparin carried over into the assay mixtures. Therefore, as an effect of heparin on the protein-phospholipid interaction has been reported [22], we had to estimate the effect of 
heparin on separate protein-lipid interactions. This was done by use of a protein-lipid equilibrium technique according to van de Waart et al. [40]. Factor $\mathrm{X}_{\mathrm{a}}(0.1 \mu M)$, factor $\mathrm{V}_{\mathrm{a}}(0.1 \mu M)$ or prothrombin $(0.05 \mu M)$ were incubated with large volume phospholipid vesicles, $25 \mu M(20 \% \mathrm{PS}-80 \% \mathrm{PC})$, in 50 $\mathrm{m} M$ Tris, $100 \mathrm{mM} \mathrm{NaCl}, \mathrm{pH} 7.5$, at $20^{\circ} \mathrm{C}$. After centrifugation for $30 \mathrm{~min}$ at $30,000 \mathrm{~g}$ at $20^{\circ} \mathrm{C}$, the concentrations of the bound proteins were estimated by determination of the remaining activity in the supernatant (factor $\mathrm{X}_{\mathrm{a}}$ was determined on $\mathrm{S} 2337$, factor $\mathrm{V}_{\mathrm{a}}$ by the factor $\mathrm{V}_{\mathrm{a}}$ assay and prothrombin after activation by Echis carinatus venom coagulant). Both heparin FF 32038 and PK 10169 at a final concentration of $0.5 \mathrm{mg} / \mathrm{ml}$ could not displace factor $\mathrm{V}_{\mathrm{a}}$, factor $\mathrm{X}_{\mathrm{a}}$ or prothrombin from the phospholipid surface. The concentrations of bound protein in the presence and absence of heparin (fraction) were: $0.02 \mu M, 0.10 \mu M, 0.03 \mu M$ for factor $\mathrm{X}_{\mathrm{a}}$, factor $\mathrm{V}_{\mathrm{a}}$ and prothrombin, respectively.

The effect of heparin on the thrombin-catalyzed factor VIII activation is measured in a clotting assay using a factor-VIII-deficient plasma; therefore heparin is carried over and indeed influences the clotting times. This problem is circumvented by making a calibration curve for the factor VIII $_{a}$ formation in the presence of the same amounts of heparin as those that are carried over. In that way, heparin does not affect the relative changes occurring during the thrombin-catalyzed factor VIII activation. In all other studies, we used a completely purified system, in which no effect of heparin carried over into the assay was observed. This was demonstrated by letting the substrate of thrombin be fully activated in the absence of heparin and adding a high heparin concentration immediately before transferring a sample to the measuring system. No effect of heparin or heparin fractions at final concentrations of up to $0.5 \mathrm{mg} / \mathrm{ml}$ was observed after a 10 - min incubation, showing that the amount of thrombin-activated substrate was independent of the presence of heparin in the activation mixture. This demonstrates that heparin did not interfere with the assembly or the functioning of the prothrombinase complex.

In the reactions where platelets are involved, we had to rule out the presence of AT III in the washed platelet preparations [41]. This was done by incubation of washed platelet suspension $\left(10^{7} / \mathrm{ml}\right)$ with $5 \mathrm{n} M$ thrombin in the presence of heparin (fractions) (10 $\mu \mathrm{g} / \mathrm{ml})$. After $20 \mathrm{~min}$, the amidolytic activity of thrombin appeared to be unaffected. In order to discriminate between an effect of heparin on the thrombin-induced factor $\mathrm{V}_{\mathrm{a}}$ generation and an effect related to the binding of heparin to platelets, we measured the effect of heparin on the beta-thromboglobulin release, induced by either thrombin or collagen. Only the thrombin-induced release of beta-thromboglobulin was affected by heparin $(90 \%$ inhibition of the release reaction at $50 \mu \mathrm{g}$ heparin $/ \mathrm{ml}$ ), showing that the reaction was occurring between thrombin and heparin and was not due to an effect of heparin on platelets.

Effect of Heparin (Fractions) on the Thrombin-Catalyzed Plasma Factor VIII Activation

We used a semi-quantitative estimation of the effect of heparin on the thrombin-catalyzed factor VIII activation. Figure 3 shows the time course of the factor VIII activation in the absence and presence of varying amounts of unfractionated heparin (FF 32038). Heparin has an effect both on the initial rate of the factor VIII activation and on 
Fig. 3. Effect of crude heparin FF 32038 on the thrombin-catalyzed factor VIII activation. Isolated factor VIII:C was incubated with thrombin $(3 \mathrm{nM})$ and varying concentrations of heparin FF 32038 . $=$ No heparin; $\mathrm{O}=0.14 \mu \mathrm{g} / \mathrm{ml} ; \Delta=0.70 \mu \mathrm{g} / \mathrm{ml} ; \Delta=1.43$ $\mu \mathrm{g} / \mathrm{ml} ;=2.9 \mu \mathrm{g} / \mathrm{ml} ; \square=5.7 \mu \mathrm{g} / \mathrm{ml}$. At timed intervals, factor $\mathrm{VIII}_{\mathrm{a}}$-containing samples were transferred to the assay. Factor $\mathrm{VIII}_{\mathrm{a}}$ was determined by using a calibration curve established with normal plasma as described in 'Materials and Methods'.

the rate of inactivation of factor $\mathrm{VIII}_{\mathrm{a}}$. It was observed that the level of factor VIII $_{\mathrm{a}}$ after 4 min was in all cases lower in the absence than in the presence of heparin. This stabilizing effect of heparin could be due to an effect either on thrombin, and/or on the factor $\mathrm{VIII}_{\mathrm{a}}$. Further experiments are required for a better understanding. We estimated the effect on the initial rate of activation, of heparin FF 32038, PK 10169 and Org 10172 (fig. 4). The $\mathrm{IC}_{50}$ values were found to be $0.5 \mu \mathrm{g} / \mathrm{ml}, 1.75$ $\mu \mathrm{g} / \mathrm{ml}$ and $25 \mu \mathrm{g} / \mathrm{ml}$, respectively.

\section{Effect of Heparin (Fractions) on the Thrombin-Catalyzed Plasma Factor $V$ Activation}

Bovine factor V $(100 \mathrm{n} M)$ was incubated at $37^{\circ} \mathrm{C}$ with calcium $(3 \mathrm{mM})$ and varying concentrations of heparin (fractions). The reaction was initiated by the addition of thrombin $(0.3 \mathrm{n} M)$. After $6 \mathrm{~min}, 1: 1,000$ diluted samples were assayed for the factor $\mathrm{V}_{\mathrm{a}}$ activity. The percentage of the residual factor $\mathrm{V}_{\mathrm{a}}$ concentration was plotted as a function of the heparin concentration (fig. 5). Determination of the $\mathrm{IC}_{50}$ values was performed

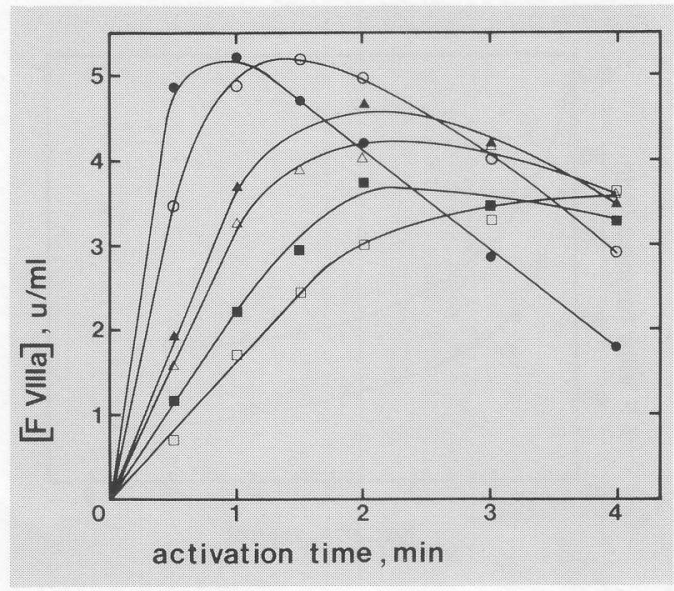

by use of the double reciprocal plot as described above (fig 5 , inset). It is clear that unfractioned heparin is a more efficient inhibitor $\left(\mathrm{IC}_{50}=10 \mu \mathrm{g} / \mathrm{ml}\right)$ than the fractions CY $216\left(\mathrm{IC}_{50}=25 \mu \mathrm{g} / \mathrm{ml}\right)$, CY $222(\mathrm{IC}=25$ $\mu \mathrm{g} / \mathrm{ml})$ or the heparinoid Org $10172\left(\mathrm{IC}_{50}=\right.$ $125 \mu \mathrm{g} / \mathrm{ml})$. The $\mathrm{IC}_{50}$ values of EMT 966 , EMT 967 and PK 10169 were $28 \mu \mathrm{g} / \mathrm{ml}, 12.5$ $\mu \mathrm{g} / \mathrm{ml}$ and $62.5 \mu \mathrm{g} / \mathrm{ml}$, respectively.

\section{Effect of Heparin Fractions on the}

Thrombin-Induced Platelet Factor $V_{a}$

Generation and on the Thrombin-plus

Collagen-Induced Platelet Procoagulant

Activity

We have previously described a direct inhibitory effect of heparin on thrombin in platelet activation [38]. We tested the effect of heparin on the thrombin-induced platelet factor $V_{a}$ generation and on the thrombinplus collagen-induced platelet procoagulant activity. We have extended the previous study to the effect of other heparin fractions, PK 10169 and 2 fractions obtained by gel filtration of PK 10169: EMT 966 and EMT 967. The results of these studies are depicted 

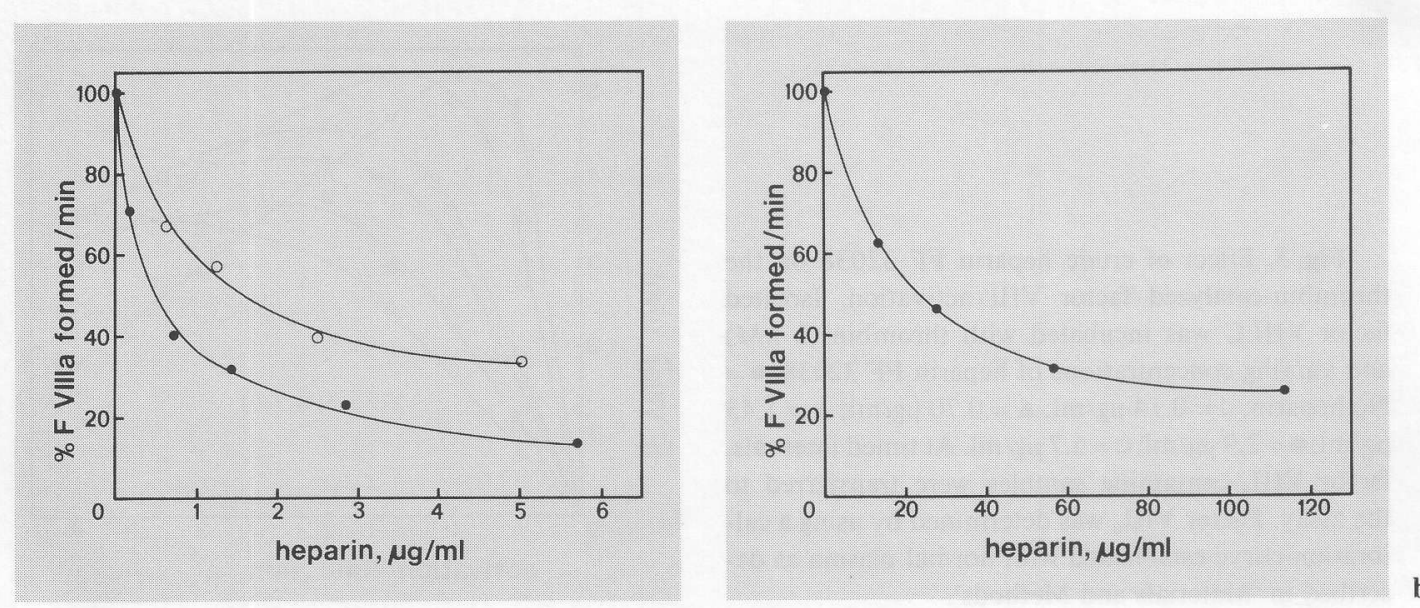

Fig. 4. Effect of heparin (fractions) on the initial rate of the thrombin-catalyzed factor VIII activation. Factor VIII:C was incubated with thrombin in the presence of varying amounts of heparin. The initial rate of the factor VIII activation was measured at $30 \mathrm{~s}$ as described in the legend to figure $3 . \mathbf{a} \bullet=\mathrm{FF} 32038 ; 0=\mathrm{PK} 10169$. b $\bullet=\operatorname{Org} 10172$.

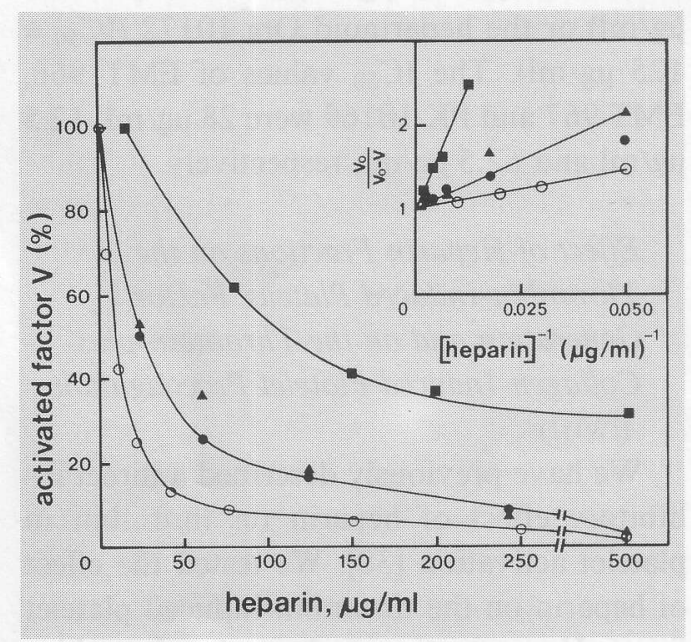

Fig. 5. Effect of heparin on the initial rate of the thrombin-catalyzed factor $\mathrm{V}$ activation: factor $\mathrm{V}(100$ $\mathrm{n} M)$ was activated for $5 \mathrm{~min}$ by thrombin $(0.3 \mathrm{n} M)$ in the presence of $\mathrm{CaCl}_{2}(3 \mathrm{mM})$ and varying concentrations of heparin. $\odot=$ Crude heparin; $\bullet$ CY $216 ; \boldsymbol{\Delta}=$ CY 222; $=$ Org 10172. Factor $V_{a}$ activity was determined as explained in 'Materials and Methods'. in table II. Whereas in the platelet factor $\mathrm{V}_{\mathrm{a}}$ generation the $\mathrm{IC}_{50}$ values are very similar $( \pm 20 \mu \mathrm{g} / \mathrm{ml})$, there are striking differences for the procoagulant activity of thrombinplus collagen-activated platelets. Heparin FF 32038 inhibited the thrombin-plus collageninduced procoagulant activity with an $\mathrm{IC}_{50}$ of $2 \mu \mathrm{g} / \mathrm{ml}$, whereas much higher concentrations of PK 10169 and EMT 967 would be required to obtain the same extent of inhibition.

\section{Conclusions}

From in vitro studies we have been able to demonstrate a direct inhibitory effect of heparin on several thrombin-dependent reactions in blood coagulation. An AT-III-independent effect of heparin is shown on the thrombin-catalyzed factor VIII activation. 
Table II. Effect of heparin on the thrombin-induced platelet factor $\mathrm{V}_{\mathrm{a}}$ generation and on the thrombinplus collagen-induced platelet procoagulant activity

\begin{tabular}{lll}
\hline Compound & \multicolumn{2}{l}{$\mathrm{IC}_{50}(\mu \mathrm{g} / \mathrm{ml})$} \\
\cline { 2 - 3 } & $\begin{array}{l}\text { factor } \mathrm{V}_{\mathrm{a}} \\
\text { generation }\end{array}$ & $\begin{array}{l}\text { procoagulant } \\
\text { activity }\end{array}$ \\
\hline FF 32038 & 18 & 2 \\
PK 10169 & 22 & $>150$ \\
EMT 966 & 25 & 17 \\
EMT 967 & 16 & $>150$ \\
\hline
\end{tabular}

Human washed platelets $\left(4.6 \times 10^{6} / \mathrm{ml}\right)$ were incubated for $3 \mathrm{~min}$ at $37^{\circ} \mathrm{C}$ with $3 \mathrm{mM}$ calcium and varying concentrations of heparin (fractions). The reaction was started with the addition of the activator (thrombin $0.5 \mathrm{n} M$ or thrombin $0.3 \mathrm{n} M$ plus collagen $5 \mu \mathrm{g} / \mathrm{ml}$ ) and after $5 \mathrm{~min}$ the respective activities were determined.

This is in agreement with the results of $O f o s u$ et al. [26] obtained by a completely different method.

In purified systems, the same effect was shown on the plasma factor $\mathrm{V}$ activation and, as demonstrated earlier [38], on the platelet factor $V_{\mathrm{a}}$ generation and platelet procoagulant activity. We have demonstrated that this effect was due to a nonspecific heparinthrombin interaction. We have not been able to confirm the observation of Walker and Esmon [24] that the AT-III-independent effect of heparin is due to interference with the protein-lipid interaction, as we performed binding experiments that allow direct determination of the protein bound to phospholipids and were unable to find any effect of heparin on this binding.

Structural characteristics of the heparin molecule have been described that are required for protease-binding: the charge den- sity of heparin is independent of the affinity for AT III, but correlates with the thrombinbinding [42], and a recent report describes that the surface charge as well as the surface charge density of heparin [43] is important in thrombin-binding.

Sulphatation seems to be an important parameter for the nonspecific binding of polysaccharides to various proteins. This not only holds for the heparin-protease interaction, but also for the inhibiting action of pentosane polysulphate [44], recently shown to be caused by inhibition of the thrombininduced factor VIII:C activation [Wagenvoord, unpublished results]. Also the interaction of heparin fractions with endothelium is seen to be strongly dependent upon the degree of sulphatation [Barzu, personal communication]. Further studies are required to better characterize the in vivo significance of this effect, as to the dissociation between antithrombotic and hemorrhagic effect of low molecular weight heparin fractions. Inhibition by heparins of the feedback activation reactions of thrombin by a process independent of AT III anyhow seems to be one of the mechanisms by which heparins modulate the thrombin formation and hence hemostasis and thrombosis.

\section{Acknowledgements}

We are grateful to Jo Franssen and Hans Hendrix for excellent technical assistance and to Mrs. T. Camphuisen for preparing the manuscript. D. Baruch was supported by a fellowship from the Institut National de la Santé et de la Recherche Médicale, Paris.

\section{References}

1 Hemker, H.C.; Lindhout, Th.: A clotting scheme for 1984. Nouv. Revue fr. Hémat. 26: 222-231 (1984). 
2 Bevers, E.M.; Comfurius, P.; van Rijn, J.L.M.L.; Hemker, H.C.; Zwaal, R.F.A.: Generation of prothrombin-converting activity and the exposure of phosphatidylserine at the outer surface of platelets. Eur. J. Biochem. 122: 429-436 (1982).

3 Rosing, J.; Tans, G.; Govers-Riemslag, J.W.P.; Zwaal, R.F.A.; Hemker, H.C.: The role of phospholipids and factor $\mathrm{V}_{\mathrm{a}}$ in the prothrombinase complex. J. biol. Chem. 255: 274-283 (1980).

4 Van Dieijen, G.; Tans, G.; Rosing, J.; Hemker, H.C.: The role of phospholipid and factor VIII in the activation of bovine factor X. J. biol. Chem. 256: 3433-3442 (1981).

5 Nemerson, Y.: Regulation of the initiation of coagulation by factor VII. Hemostasis 13: 150-155 (1983).

6 Miletich, J.P.; Kane, W.H.; Hofman, S.L.; Stanford, N.; Majerus, P.W.: Deficiency of factor $\mathrm{X}_{\mathrm{a}}$ factor $\mathrm{V}_{\mathrm{a}}$ binding site on the platelets of a patient with a bleeding disorder. Blood 54: 1015-1022 (1979).

7 Jordan, R.; Beeler, D.; Rosenberg, R.: Fractionation of low molecular weight heparin species and their interaction with antithrombin. J. biol. Chem. 254: 2902-2913 (1979).

8 Olson, S.T.; Shore, J.D.: Binding of high affinity heparin to antithrombin III. Characterization of the protein fluorescence enhancement. J. biol. Chem. 256: 11065-11072 (1981).

9 Machovich, R.; Blasko, G.; Palos, L.A.: Action of heparin on thrombin-antithrombin reaction. Biochim. biophys. Acta 379: 193-200 (1975).

10 Griffith, M.J.: Kinetic analysis of the heparinenhanced antithrombin III-thrombin reaction. J. biol. Chem. 254: 12044-12049 (1979).

11 Pomerantz, M.W.; Owen, W.G.: A catalytic role for heparin. Evidence for a ternary complex of heparin cofactor thrombin and heparin. Biochim. biophys. Acta 535: 66-77 (1978).

12 Nesheim, M.E.: A simple rate law that describes the kinetics of the heparin-catalyzed reaction between antithrombin III and thrombin. J. biol. Chem. 258: 14708-14717 (1983).

13 Griffith, M.J.: The heparin-enhanced antithrombin III/thrombin reaction is saturable with respect to both thrombin and antithrombin III. J. biol. Chem. 257: 13899-13902 (1982).

14 Choay, J.; Petitou, M.; Lormeau, M.C.; Sinay, P.; Casu, B.J.; Gatti, G.: Structure activity relationship in heparin: a synthetic pentasaccharide with high affinity for antithrombin III and eliciting high anti factor $\mathrm{X}_{\mathrm{a}}$ activity. Biochem. biophys. Res. Commun. 116: 492-499 (1983).

15 Holmer, E.; Kurachi, K.; Soderstrom, G.: The molecular weight dependence of the rate-enhancing effect of heparin on the inhibition of thrombin factor $\mathrm{X}_{\mathrm{a}}$, factor $\mathrm{IX}_{\mathrm{a}}$, factor $\mathrm{XI}_{\mathrm{a}}$, factor $\mathrm{XII}_{\mathrm{a}}$ and kallikrein by antithrombin III. Biochem. J. 193: 395-400 (1981).

16 Lane, A.; Denton, J.; Flynn, A.M.; Thunberg, L.; Lindahl, U.: Anticoagulant activities of heparin oligosaccharides and their neutralization by platelet factor 4. Biochem. J. 218: 725-732 (1984).

17 Tollefsen, D.M.; Blank, M.K.: Detection of a new heparin-dependent inhibitor of thrombin in human plasma. J. clin. Invest. 68: 589-596 (1981).

18 Marciniak, E.: Factor $\mathrm{X}_{\mathrm{a}}$ inactivation by antithrombin III. Evidence for biological stabilization of factor $\mathrm{X}_{\mathrm{a}}$ by factor- $\mathrm{V}$-phospholipid complex. Br. J. Haemat. 24: 391-400 (1973).

19 Josso, F.; Béguin, S.: Changes in the antithrombin III activity at the interface plasma-phospholipids (Abstract). Thromb. Haemostasis 46: 285 (1981).

20 Ellis, V.; Scully, M.F.; Kakkar, V.V.: Inhibition of prothrombinase complex by plasma proteinase inhibitors. Biochemistry 23: 5882-5887 (1984).

21 Teitel, J.M.; Rosenberg, R.D.: Protection of factor $\mathrm{X}_{\mathrm{a}}$ from neutralization by the heparin-antithrombin complex. J. clin. Invest. 71: 1383-1391 (1983).

22 Ockelford, P.; Carter, C.J.; Cerskus, A.; Smith, C.A.; Hirsh, J.: Comparison of the in vivo haemorrhagic and antithrombotic effects of a low antithrombin III affinity heparin fraction. Thromb. Res. 27: 679-690 (1982).

23 Barrowcliffe, T.W.; Merton, R.E.; Havercroft, S.J.; Thunberg, U.; Thomas, D.P.: Low affinity heparin potentiates the action of high affinity heparin oligosaccharides. Thromb. Res. 34: 125-133 (1984).

24 Walker, F.J.; Esmon, C.T.: Interactions between heparin and factor $\mathrm{X}_{\mathrm{a}}$. Inhibition of prothrombin activation. Biochim. biophys. Acta 585: 405-415 (1979).

25 Brown, J.E.; Baugh, R.F.; Hougie, C.: The inhibition of the intrinsic generation of activated factor $\mathrm{X}$ by heparin and hirudin. Thromb. Res. 17: 267$272(1980)$

26 Ofosu, F.A.; Blajchman, M.A.; Hirsh, J.: The inhibition by heparin of the intrinsic pathway activation of factor $\mathrm{X}$ in the absence of antithrombin III. Thromb. Res. 20: 391-403 (1980). 
27 Ofosu, F.A.; Blajchman, M.A.; Modi, G.; Cerskus, A.L.; Hirsh, J.: Activation of factor $\mathrm{X}$ and prothrombin in antithrombin-III-depleted plasma: the effects of heparin. Thromb. Res. 23: 331-345 (1981).

28 Ofosu, F.A.; Modi, G.; Cerskus, A.L.; Hirsh, J.; Blajchman, M.A.: Heparin with low affinity to antithrombin III inhibits the activation of prothrombin in normal plasma. Thromb. Res. 28 . 487-497 (1982).

29 Lecrubier, C.; Conard, J.; Horellou, M.H.; Kher, A.; Samama, M.: Spontaneous platelet aggregation in heparin-treated patients. Acta Haemat. 71: 6365 (1984).

30 Kelton, J.G.; Hirsh, J.: Bleeding associated with antithrombotic therapy. Semin. Hematol. 17: 375379 (1980).

31 Harker, L.A.; Molpass, T.W.; Branson, H.E.; Hessel, E.A.; Slichter, S.J.: Mechanism of abnormal bleeding in patients undergoing cardiopulmary bypass: acquired transient dysfunction associated with selective alpha-granule release. Blood 56 : 824-834 (1980).

32 Salzman, E.W.; Rosenberg, R.D.; Smith, M.H.; Lindon, J.N.; Favreau, L.: Effect of heparin and heparin fractions on platelet aggregation. J. clin. Invest. 65: 64-73 (1980).

33 Hirsh, J.: Heparin-induced bleeding. Nouv. Revue fr. Hémat. 26: 261-266 (1984).

34 Kakkar, V.V.; Djazaeri, D.B.; Webb, P.; Scully, M.; Westwick, T.; MacGregor, I.: Low molecular weight heparin and prevention of postoperative deep vein thrombosis. Br. med. J. 284: 375-379 (1982).

35 Huisse, M.G.; Guillin, M.C.; Bezeaud, A.; Toulemonde, F.; Kitzis, M.; Adreassian, B.: Heparinassociated thrombocytopenia. In vitro effect of different low molecular weight heparin fractions. Thromb. Res. 27: 485-490 (1982).

36 Henny, C.P.; Ten Cate, J.W.; van Bronswijck, H.; Ten Cate, H.; Surachino, S.; Wilmink, J.M.; Ockelford, P.A.: Use of a new heparinoid as anticoagulant during acute hemodialysis of patients with bleeding complications. Lancet $i$ : 890-893 (1983).

37 Aiach, M.; Michaud, A.; Balian, J.L.; Lefebvre, M.; Woler, M.; Fourtillan, J.: A new low molecular weight heparin derivative. In vitro and in vivo studies. Thromb. Res. 31: 611-621 (1983).
38 Baruch, D.; Franssen, J.; Hemker, H.C.; Lindhout, T.: Effect of heparin and low molecular weight heparins on thrombin-induced blood platelet activation in the absence of antithrombin III. Thromb. Res. 38: 447-458 (1985).

39 Griffith, M.J.; Kingdon, H.S.; Lundblad, R.L.: The interaction of heparin with human alphathrombin: effect on the hydrolysis of aniline tripeptide substrates. Archs Biochem. Biophys. 195: 378-384 (1979)

40 Van de Waart, P.; Bruls, H.; Hemker, H.C.; Lindhout, $\mathrm{T}$.: Interaction of bovine blood clotting factor $\mathrm{V}_{\mathrm{a}}$ and its subunit with phospholipid vesicles. Biochemistry 22: 2427-2432 (1983).

$41 \mathrm{Kim}$, B.K.; Steiner, M.; Baldini, M.G.: Antithrombin III binds to human platelets. Biochem. Biophys. Res. Commun. 97: 1227-1232 (1980).

42 Hurst, R.E.; Poon, M.C.; Griffith, M.J.: Structureactivity relationships of heparin. Independence of heparin charge density and antithrombin-binding domains in thrombin inhibition by antithrombin and heparin cofactor II. J. clin. Invest. 72: 10421045 (1983).

43 Heuck, C.C.; Schiele, U.; Horn, D.; Fronda, D.; Ritz, E.: The role of surface charge in the accelerating action of heparin on the antithrombin-IIIinhibited activity of thrombin. J. biol. Chem. 260: 4598-4603 (1985).

44 Fischer, A.M.; Barrowcliffe, T.W.; Thomas, D.P.: A comparison of pentosan polysulphate and heparin. I. Mechanism of action on blood coagulation. Thromb. Haemostasis 47: 104-108 (1982).

Dr. D. Baruch,

Department of Biochemistry,

Biomedical Center,

University of Limburg,

PO Box 616 ,

NL-6200 MD Maastricht (The Netherlands) 